\title{
Metabolic Loss of Deuterium from Isotopically Labeled Glucose
}

\author{
Oded Ben-Yoseph, Peter B. Kingsley, Brian D. Ross
}

\begin{abstract}
The isotopically substituted molecule $\left(6-{ }^{-13} \mathrm{C}, 1,6,6-{ }^{2} \mathrm{H}_{3}\right)$ glucosse was evaluated to determine whether metabolic ${ }^{2} \mathrm{H}$ loss would prevent its use in quantitating pentose phosphate pathway (PPP) activity. PPP activity causes the $\mathrm{C} 1$ of glucose to be lost as $\mathrm{CO}_{2}$, while $\mathrm{C} 6$ can appear in lactate. ${ }^{2} \mathrm{H}$ NMR analysis of the lactate produced from this glucose can distinguish $\left(3-{ }^{2} \mathrm{H}\right)$ lactate (from $\mathrm{C} 1$ of glucose) from $\left(3{ }^{13} \mathrm{C}, 3,3-{ }^{2} \mathrm{H}_{2}\right.$ )lactate (from C6 of glucose). ${ }^{2} \mathrm{H}$ NMR spectroscopic analysis of medium containing $\left(6-{ }^{13} \mathrm{C}, 1,6,6-{ }^{2} \mathrm{H}_{3}\right)$ glucose after incubation with cultured rat $9 \mathrm{~L}$ glioma cells suggested a $30.8 \pm 2.1 \%$ PPP activity as compared with $6.0 \pm 0.8 \%$ from separate, parallel incubations with $\left(1-{ }^{13} \mathrm{C}\right)$ glucose and $\left(6-{ }^{13} \mathrm{C}\right)$ glucose. Subsequent experiments with other isotopically labeled glucose molecules suggest that this discrepancy is due to selective loss of ${ }^{2} \mathrm{H}$ from the $\mathrm{C} 1$ position of glucose, catalyzed by phosphomannose isomerase. Failure to consider ${ }^{2} \mathrm{H}$ exchange from the $\mathrm{C1}$ and $\mathbf{C} 6$ positions of glucose can lead to incorrect conclusions in metabolic studies utilizing this and other deuterated or tritiated glucose molecules.
\end{abstract}

Key words: deuterium NMR spectroscopy; pentose phosphate pathway; deuterium loss; phosphomannose isomerase.

\section{INTRODUCTION}

The noninvasiveness and chemical specificity of NMR spectroscopy allow for continuous monitoring of various metabolites in intact biological systems. One advantage of ${ }^{2} \mathrm{H}$ NMR is the low natural abundance of ${ }^{2} \mathrm{H}(0.015 \%)$, resulting in very little interference from endogenous compounds and allowing the $16 \mathrm{mM} \mathrm{H}^{2} \mathrm{HO}$ resonance to be used as a chemical shift and intensity standard $(1,2)$. The chemical shifts of the resonances in ${ }^{2} \mathrm{H}$ and ${ }^{1} \mathrm{H}$ NMR spectra are similar, rendering assignment and identification relatively easy. ${ }^{2} \mathrm{H}$ NMR spectra are less well resolved than ${ }^{1} \mathrm{H}$ or ${ }^{13} \mathrm{C}$ spectra as a result of 1 ) a smaller frequency range, due to the lower gyromagnetic ratio, and 2) increased line width due to quadrupolar relaxation. The faster $T_{1}$ relaxation of the ${ }^{2} \mathrm{H}$ nucleus allows

MRM 32:405-409 (1994)

From the Departments of Radiology and Biological Chemistry, School of Medicine, University of Michigan Medical Center, Ann Arbor, Michigan; and the Department of Diagnostic Imaging, St. Jude Children's Research Hospital, Memphis, Tennessee (P.B.K.)

Address correspondence to: Brian D. Ross, Ph.D., Department of Radiology, University of Michigan, Medical Center, Kresge III Research Building, Ann Arbor, Ml 48109-0553.

Received February 8, 1994; revised May 25, 1994; accepted May 31, 1994. These studies were supported in part by a Research Investigation Grant from the American Cancer Society (Grant \#BE-149), an Institutional Research Grant (\#IN-40-32) to the University of Michigan Cancer Center from the American Cancer Society, NIH Grants R29 CA59009 and P20 NS31114, Cancer Center Support (CORE) Grant P30 CA21765, and the American Lebanese Syrian Associated Charities (ALSAC).

0740-3194/94 \$3.00

Copyright (C) 1994 by Williams \& Wilkins

All rights of reproduction in any form reserved. for shorter interpulse delays and faster data acquisition, thus partially compensating for its decreased relative sensitivity $\left(\sim 1 \%\right.$ of ${ }^{1} \mathrm{H}, \sim 60 \%$ of $\left.{ }^{13} \mathrm{C}\right)$. The metabolic exchange of ${ }^{2} \mathrm{H}$ or ${ }^{3} \mathrm{H}$ atoms with water (2-10) allows for the study of these exchange reactions. However, failure to consider the various exchange reactions may lead to erroneous conclusions.

There is considerable interest in monitoring the activity of the pentose phosphate pathway (PPP) since the NADPH produced by this pathway is important for antioxidant defense and for nucleotide synthesis. PPP activity can be quantitated by measuring the selective loss of the $\mathrm{C} 1$ position of glucose in the reaction catalyzed by phosphogluconate dehydrogenase, for example, by comparing ${ }^{14} \mathrm{CO}_{2}$ production from $\left[1-{ }^{14} \mathrm{C}\right]$ glucose and $\left[6-{ }^{14} \mathrm{C}\right]-$ glucose (11). An alternative approach is to measure the amount of label appearing in lactate or other metabolites, rather than in $\mathrm{CO}_{2}$, after incubation with labeled glucose as a precursor. For instance, metabolism of $\left(1-{ }^{13} \mathrm{C}\right)$ glucose through the glycolytic pathway will produce $\left(3{ }^{-13} \mathrm{C}\right)$ lactate and unlabeled lactate, which can be differentiated by ${ }^{1} \mathrm{H}$ NMR spectroscopy (12) or gas chromatography/mass spectrometry (GC/MS) (13). The ${ }^{1} \mathrm{H}$ NMR doublet signal $\left(U_{\mathrm{HH}} \sim 7 \mathrm{~Hz}\right)$ of the methyl group of $\left(3{ }^{13} \mathrm{C}\right)$ lactate will be split by scalar heteronuclear coupling into a pair of doublets $\left(J_{\mathrm{HC}} \sim 125 \mathrm{~Hz}\right)$, which can be distinguished from the single doublet of unlabeled lactate (12). As PPP activity increases, the $\left(3-^{13} \mathrm{C}\right)$ lactate resonance intensities decline relative to the intensity of the unlabeled lactate resonance. To obtain accurate PPP measurements, a parallel incubation with $\left(6-{ }^{13} \mathrm{C}\right)$ glucose is necessary to correct for unlabeled lactate from endogenous carbon sources (14).

In this study, we investigated the use of a novel isotopically substituted molecule, $\left(6-{ }^{13} \mathrm{C}, 1,6,6-{ }^{2} \mathrm{H}_{3}\right)$ glucose, to measure PPP activity in a single incubation. ${ }^{2} \mathrm{H}$ NMR spectroscopy was used to analyze the lactate produced in medium containing $\left(6-{ }^{13} \mathrm{C}, 1,6,6-{ }^{2} \mathrm{H}_{3}\right)$ glucose after incubation with cultured rat $9 \mathrm{~L}$ glioma cells (obtained from the Brain Tumor Research Center at the University of California at San Francisco). Absolute quantitation of PPP activity using $\left(6-{ }^{13} \mathrm{C}, 1,6,6-{ }^{2} \mathrm{H}_{3}\right)$ glucose was complicated by the loss of ${ }^{2} \mathrm{H}$ atoms during metabolism. A significant loss of ${ }^{2} \mathrm{H}$ atoms from $\mathrm{C} 1$ and $\mathrm{C} 6$ was detected in separate GC/MS measurements using $\left(1{ }^{-13} \mathrm{C}, 1-{ }^{2} \mathrm{H}\right)$ glucose and (6${ }^{13} \mathrm{C}, 6,6-{ }^{2} \mathrm{H}_{2}$ )glucose, respectively. Loss of ${ }^{2} \mathrm{H}$ from $\mathrm{C} 6$ of glucose was attributed to the catalytic action of pyruvate kinase (PK). Loss of ${ }^{2} \mathrm{H}$ from $\mathrm{C} 1$ of glucose was attributed to both PK and phosphomannose isomerase (PMI). To verify the presence of PMI, enzymatic assays of 9L glioma and rat brain extracts were performed. The extent of these ${ }^{2} \mathrm{H}$ exchange reactions must be known before conclusions from metabolic studies utilizing this and other deuterated or tritiated glucose molecules can be made. 


\section{METHODS}

Theory of PPP Measurement Using $\left(6-^{13} \mathrm{C}, 1,6,6-{ }^{2} \mathrm{H}_{3}\right)$ Glucose

Metabolism of $\left(6-{ }^{13} \mathrm{C}, 1,6,6-{ }^{2} \mathrm{H}_{3}\right)$ glucose through glycolysis will result in the formation of $\left(3{ }^{13} \mathrm{C}, 3,3-{ }^{2} \mathrm{H}_{2}\right)$ lactate and $\left(3-{ }^{2} \mathrm{H}\right)$ lactate, whereas metabolism through the PPP will result in $\left(3-{ }^{13} \mathrm{C}, 3,3-{ }^{2} \mathrm{H}_{2}\right)$ lactate and unlabeled lactate (Fig, 1). Because the ${ }^{2} \mathrm{H}-{ }^{1} \mathrm{H}$ coupling is not resolved in the ${ }^{2} \mathrm{H}$ NMR spectrum, the methyl ${ }^{2} \mathrm{H}$ resonance of [C6]lactate (lactate containing $\mathrm{C} 6$ of glucose) is split into two peaks by the neighboring ${ }^{13} \mathrm{C}$, and is easily distinguished from the central [C1]lactate peak. Assuming no PPP activity and no loss of ${ }^{2} \mathrm{H}$ atoms, a pseudotriplet of equal intensities is expected. As PPP activity is increased, an increased loss of deuterium label from the C1 position of glucose will take place via the catalytic action of glucose 6-phosphate dehydrogenase, leading to a decrease in the intensity of the central singlet resonance. This method is a "mirror image" of the ${ }^{1} \mathrm{H}$ NMR detection of lactate pro-

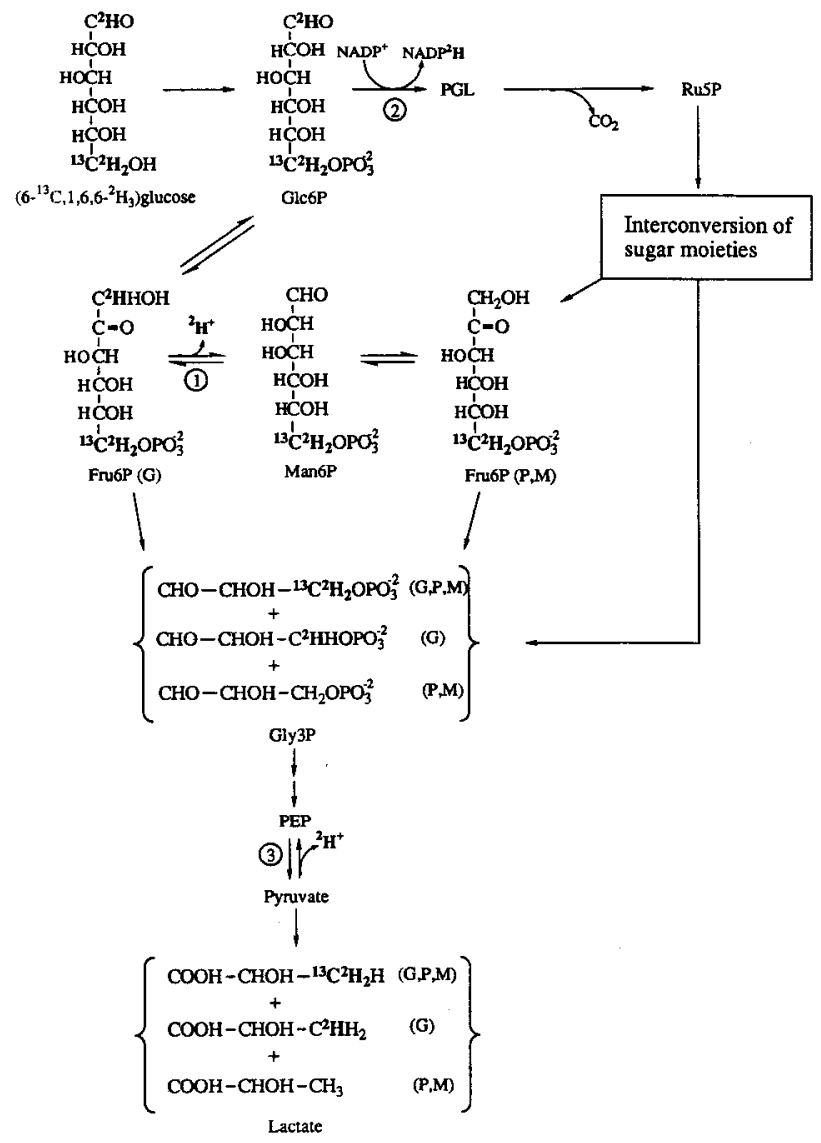

FIG. 1. The fate of $\left(6-{ }^{13} \mathrm{C}, 1,6,6-{ }^{2} \mathrm{H}_{3}\right)$ glucose through glycolysis and the pentose phosphate pathway. Reactions that result in ${ }^{2} \mathrm{H}$ loss include: 1. phosphomannose isomerase; 2. glucose 6-phosphate dehydrogenase; and 3. pyruvate kinase. $G, P$, and $M$ indicate the origin of a metabolite from glycolysis, PPP, and PMI, respectively. Interconversion of sugar moieties refers to the nonoxidative branch of the PPP. The following abbreviations are used: Glc6P, glucose 6-phosphate; PGL, phosphogluconolactone; Ru5P, ribulose 5-phosphate; Man6P, mannose 6-phosphate; Fru6P, fructose 6-phosphate; Gly3P, glyceraldehyde 3-phosphate; PEP, phosphoenolpyruvate. duced from $\left(1-{ }^{13} \mathrm{C}\right)$ glucose, as described above. The advantage of the ${ }^{2} \mathrm{H}$ approach is that lactate produced from endogenous sources contains negligible amounts of ${ }^{2} \mathbf{H}$ and therefore does not interfere with the measurement.

\section{Calculation of PPP Activity}

PPP activity is reported as $P$, the fraction of glucose metabolized to lactate that lost $\mathrm{C} 1$ as $\mathrm{CO}_{2}$ as it passed through the PPP. PPP activity can be determined from metabolism of glucose labeled with distinct isotopes in the $\mathrm{C} 1$ and $\mathrm{C} 6$ positions by the general formula $P=1-$ [C1]lactate/[C6]lactate, where [C1]lactate and [C6]lactate are the relative amounts of lactate derived from $\mathrm{C} 1$ and C6 of glucose, respectively $(14,15)$. PPP activity was calculated from ${ }^{2} \mathrm{H}$ NMR spectra using the formula $P_{\mathrm{NMR}}$ $=(1-\mathrm{R}) \cdot 100$, where $P_{\mathrm{NMR}}$ is the percentage of glucose metabolized through the PPP, and $R$ is the ratio of the peak areas of $\left(3{ }^{2} \mathrm{H}_{n}\right)$ lactate to $\left(3{ }^{13} \mathrm{C}, 3-{ }^{2} \mathrm{H}_{n}\right)$ lactate $(n=1$ or 2), corrected for the number of ${ }^{2} \mathrm{H}$ atoms, for natural isotope abundance ( $\mathrm{C} 1$ is $98.9 \%{ }^{12} \mathrm{C}$ and $1.1 \%{ }^{13} \mathrm{C}$ ) and for fractional enrichment:

$$
R=\frac{\left[L_{\mathrm{C} 6} \cdot\left(3-{ }^{2} \mathrm{H}\right) \text { lactate }-\left(1-L_{\mathrm{C} 6}\right)\right.}{\left.\cdot\left(3-{ }^{13} \mathrm{C}, 3-{ }^{2} \mathrm{H}_{\mathrm{n}}\right) \text { lactate }\right] \cdot\left[L_{\mathrm{H} 6 \mathrm{a}}+L_{\mathrm{H} 6 \mathrm{~b}}\right]} .
$$

This equation includes an adjustment for the fractional enrichment of ${ }^{13} \mathrm{C}$ in $\mathrm{C} 6\left(L_{\mathrm{C} 6}\right)$, and of ${ }^{2} \mathrm{H}$ at $\mathrm{C} 1\left(L_{\mathrm{H} 1}\right)$ and in the two positions at $\mathrm{C} 6\left(L_{\mathrm{HGa}}\right.$ and $\left.L_{\mathrm{H} 6 \mathrm{~b}}\right)$. In the present study $L_{\mathrm{C} 6}=0.99, L_{\mathrm{H} 1}=0.99, L_{\mathrm{H} 6 \mathrm{a}}=0.985$ and $L_{\mathrm{H} 6 \mathrm{~b}}=$ 0.975.

For GC/MS measurements, [C1] lactate and [C6]lactate correspond roughly to the $\mathrm{m} / \mathrm{z} 220$ ion and $\mathrm{m} / \mathrm{z} 221+$ $\mathrm{m} / \mathrm{z} 222$ ions, respectively (15).

\section{Cell Culture Incubation Procedures}

$\left(6-{ }^{13} \mathrm{C}, 1,6,6-{ }^{2} \mathrm{H}_{3}\right)$ Glucose was synthesized by Omicron Biochemicals Inc. (South Bend, IN). For GC/MS measurements, glioma cells were grown in 24-well culture flasks until confluent. The growth medium was removed and the cells were rinsed 3 times with Krebs-Ringer bicarbonate buffer (KRB) and incubated in $0.5 \mathrm{ml} /$ well $\mathrm{KRB}$ containing $5.5 \mathrm{mM}\left(6-{ }^{13} \mathrm{C}, 1,6,6-{ }^{2} \mathrm{H}_{3}\right)$ glucose or another labeled glucose. After a 1-h incubation period, media were removed and lyophilized for isotopic analysis of lactate by GC/MS. For ${ }^{2} \mathrm{H}$ NMR experiments, the cells were grown in $175 \mathrm{~cm}^{2}$ culture flasks and incubated with $12 \mathrm{ml}$ of $5.5 \mathrm{mM}\left(6-{ }^{13} \mathrm{C}, 1,6,6-{ }^{2} \mathrm{H}_{3}\right)$ glucose in KRB for $1 \mathrm{~h}$. The incubation medium was then removed, lyophilized, and reconstituted in $0.5 \mathrm{ml} \mathrm{H}_{2} \mathrm{O}$.

To quantitate the extent of ${ }^{2} \mathrm{H}$ loss from the $\mathrm{C} 1$ and $\mathrm{C6}$ positions of glucose during metabolism to lactate, media from separate incubations of 9L glioma cells with $5.5 \mathrm{mM}$ $\left(1-{ }^{13} \mathrm{C}, 1-{ }^{2} \mathrm{H}\right)$ glucose and $5.5 \mathrm{mM}\left(6-{ }^{13} \mathrm{C}, 6,6-{ }^{2} \mathrm{H}_{2}\right)$ glucose, respectively, were analyzed by GC/MS.

\section{GC/MS and ${ }^{2} \mathrm{H}$ NMR Measurements}

GC/MS measurements were performed as previously described (13) using a bench top Hewlett Packard GC/MS system (Model 5890/5971). 
${ }^{2} \mathrm{H}$ NMR spectra were obtained on a 7 Tesla Nicolet NMR spectrometer equipped with a vertical-bore magnet with a 5-mm probe, using a single-pulse-excitation sequence with the acquisition parameters as follows: 2000 transients; pulse width, $45 \mu \mathrm{s}$; repetition time, $1.3 \mathrm{~s}$; spectral width, $\pm 600 \mathrm{~Hz}$; transmitter frequency, $46.1 \mathrm{MHz}$. Because the ${ }^{2} \mathrm{H}$ lock channel was used for RF excitation and reception, all spectra were acquired in the unlocked mode. NMR and GC/MS data are reported as mean \pm SD.

\section{Tissue and Cell Extraction}

Male Fisher rats (120-150g) were anesthetized (ketamine, intraperitoneal, $65 \mathrm{mg} / \mathrm{kg}$ ) and exsanguinated, and the brains were quickly removed. The two cerebral hemispheres were separated and the white matter and hippocampus were removed. Each cortex was placed in a Thomas BB teflon homogenizer containing $2 \mathrm{ml}$ ice-cold Tris-HCl ( $\mathrm{pH}$ 8.5). The tissues were homogenized manually and the homogenates were centrifuged at $4^{\circ} \mathrm{C}$ for 20 min at $3500 \mathrm{rpm}$. Supernatants were then collected and enzyme analyses immediately performed.

Cultured 9L glioma cells were trypsinized for $5 \mathrm{~min}$ at $37^{\circ} \mathrm{C}$ and centrifuged for $10 \mathrm{~min}$ at $1500 \mathrm{rpm}$. The supernatant was discarded and the pellet resuspended in $1 \mathrm{ml}$ Tris-HCl. Homogenization and extraction were then conducted as described above.

\section{Enzyme Assays}

PMI activity in rat cortex and extracts of cultured 9L glioma cells was measured spectrophotometrically in a coupled enzymatic reaction after the conversion of mannose 6-phosphate (Man6P) to fructose 6-phosphate (Fru6P) by PMI and conversion of Fru6P to glucose 6-phosphate (Glc6P) by phosphoglucose isomerase (16). Reduction of $\mathrm{NADP}^{+}$to NADPH by glucose 6-phosphate dehydrogenase (G6PDH) was monitored at $340 \mathrm{~nm}$ with a Perkin-Elmer Lambda 6 double-beam spectrophotometer. The 1-ml reaction mixture contained $25 \mathrm{mM}$ Tris- $\mathrm{HCl}(\mathrm{pH}$ 8.5), $3 \mathrm{~m} M$ Man6P, $1 \mathrm{mM} \mathrm{NADP}^{+}, 5 \mathrm{~m} M \mathrm{MgCl}_{2}$, $0.5 \mathrm{U}$ phosphoglucose isomerase, $1 \mathrm{U} \mathrm{G6PDH}$, and $100 \mu \mathrm{lex}$ tract.

G6PDH was assayed using previously reported methods (17). Reduction of $\mathrm{NADP}^{+}$at $30^{\circ} \mathrm{C}$ was followed at $340 \mathrm{~nm}$. The $3-\mathrm{ml}$ reaction mixture contained $0.75 \mathrm{mM}$ Gle6P, $0.5 \mathrm{mM} \mathrm{NADP}^{+}, 4 \mathrm{mM}$ maleimide, and $1 \mathrm{mM}$ $\mathrm{MgSO}_{4}$. Total protein in the extracts was determined spectrophotometrically by a modified Lowry procedure (18) using a protein determination kit (Sigma Chemical Inc.).

\section{RESULTS AND DISCUSSION}

The ${ }^{2} \mathrm{H}$ NMR spectrum shown in Fig. 2 was obtained from the medium of $9 \mathrm{~L}$ glioma cells after incubation with (6${ }^{13} \mathrm{C}, 1,6,6-{ }^{2} \mathrm{H}_{3}$ )glucose. The pseudotriplet near $1.3 \mathrm{ppm}$ is from ${ }^{2} \mathrm{H}$ atoms on the methyl group of lactate. The central resonance at $1.39 \mathrm{ppm}$ corresponds to the ${ }^{2} \mathrm{H}$ atom attached to ${ }^{12} \mathrm{C}$, derived from the $\mathrm{C} 1$ of $\left(6-{ }^{13} \mathrm{C}, 1,6,6-{ }^{2} \mathrm{H}_{3}\right)$ glucose, while the satellite resonances at $1.58 \mathrm{ppm}$ and $1.15 \mathrm{ppm}$ arise from ${ }^{2} \mathrm{H}$ atoms attached to ${ }^{13} \mathrm{C}$, derived

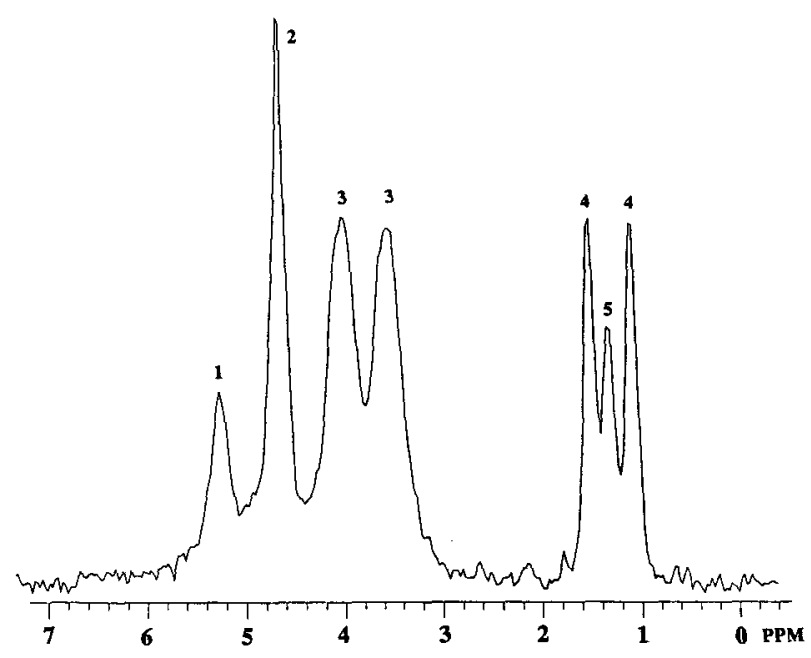

FIG. 2. Representative ${ }^{2} \mathrm{H}$ NMR spectrum of the incubation medium taken from $9 \mathrm{~L}$ glioma cells after incubation with $5.5 \mathrm{mM}$ $\left(6-{ }^{13} \mathrm{C}, 1,6,6-{ }^{2} \mathrm{H}_{3}\right)$ glucose in KRB for $1 \mathrm{~h}$. PPP activity $\left(P_{\mathrm{NMR}}=30.8\right.$ $\pm 2.1 \%, n=4)$ was calculated fron the formula $P_{\text {NMR }}=(1-R) \times$ 100 where $R$ is defined in Eq. [1]. Resonance assignments are as follows: (1) ${ }^{2} \mathrm{H}$ on $\mathrm{C} 1$ of $\alpha-\left(6-{ }^{13} \mathrm{C}, 1,6,6-{ }^{2} \mathrm{H}_{3}\right)$ glucose, (2) $\mathrm{H}^{2} \mathrm{HO}$, (3) ${ }^{2} \mathrm{H}$ on $\mathrm{C} 6$ of $\left(6-{ }^{13} \mathrm{C}, 1,6,6-{ }^{2} \mathrm{H}_{3}\right)$ glucose, $(4)\left(3-{ }^{13} \mathrm{C}, 3,3-{ }^{2} \mathrm{H}_{2}\right)$ lactate and $\left(3-{ }^{13} \mathrm{C}, 3-{ }^{2} \mathrm{H}\right)$ lactate, $(5)\left(3-{ }^{2} \mathrm{H}\right)$ lactate.

from the C6 of $\left(6-{ }^{13} \mathrm{C}, 1,6,6-{ }^{2} \mathrm{H}_{3}\right)$ glucose. The positions of the latter resonances are shifted by spin-spin coupling between the ${ }^{2} \mathrm{H}$ and ${ }^{13} \mathrm{C}$ nuclei. The reduced intensity of the central ${ }^{2} \mathrm{H}$ resonance, derived from $\mathrm{C} 1$ of glucose, suggests a significant PPP activity. Calculation of PPP activity from ${ }^{2} \mathrm{H}$ NMR and from GC/MS spectra gave $P=$ $30.8 \pm 2.1 \%(n=4 \pm \mathrm{SD})$ and $P=29.2 \pm 2.2 \%(n=6 \pm$ $\mathrm{SD}$, respectively.

This PPP activity, however, is not consistent with the $6.0 \pm 0.8 \%$ basal PPP activity found in parallel incubations with $\left(1-{ }^{13} \mathrm{C}\right)$ glucose and $\left(6-{ }^{13} \mathrm{C}\right)$ glucose by GC/MS (14). The use of $\left(6{ }^{13} \mathrm{C}, 1,6,6-{ }^{2} \mathrm{H}_{3}\right)$ glucose resulted in an overestimation of basal PPP activity which was presumed to be the result of excess loss of ${ }^{2} \mathrm{H}$ from the $\mathrm{C} 1$ position of glucose by metabolic reactions unrelated to the PPP. This suggestion was further enforced when GC/MS analysis of lactate after incubations with (1,6${ }^{13} \mathrm{C}_{2}, 6,6-{ }^{2} \mathrm{H}_{2}$ )glucose gave a basal PPP activity of $4.7 \pm$ $0.6 \%$ (15). Because $\left(1,6-{ }^{13} \mathrm{C}_{2}, 6,6-{ }^{2} \mathrm{H}_{2}\right)$ glucose, which does not have a ${ }^{2} \mathrm{H}$ atom on $\mathrm{C} 1$, yielded accurate PPP values, the selective loss of ${ }^{2} \mathrm{H}$ from the $\mathrm{C} 1$ position of (6${ }^{13} \mathrm{C}, 1,6,6-{ }^{2} \mathrm{H}_{3}$ )glucose is the most plausible explanation for the inability of $\left(6-{ }^{13} \mathrm{C}, 1,6,6-{ }^{2} \mathrm{H}_{3}\right)$ glucose to quantitate PPP activity.

One metabolic reaction which may result in specific ${ }^{2} \mathrm{H}$ loss from the $\mathrm{C} 1$ position is the reversible conversion of Fru6P to Man6P, catalyzed by PMI (Fig. 1). Mannose is a major component of glycoproteins (19), and specific enzymes related to the formation of mannose-rich oligosaccharides have been identified in the brain $(20,21)$. Mannose has also been linked to neurotransmission as dopaminergic agonists were reported to stimulate glycosylation of proteins in the rat and mouse hippocampus, cortex, and striatum (22). The catalytic action of PMI may cause ${ }^{2} \mathrm{H}$ loss when the $\mathrm{C} 1$ alcohol group in Fru6P is 
oxidized to an aldehyde (Fig. 3a). Studies of the PMI reaction mechanism using $\left(1-{ }^{2} \mathrm{H}\right)$ Fru6P have shown that this isomerase is stereospecific for one of the two hydrogen atoms on the $\mathrm{C} 1$ position of Fru6P and that the reaction results in a release of deuterium from the substrate into the medium (3). In addition, yeast PMI had only $5-7 \%$ retention of tritium in the conversion of $\left[2-{ }^{3} \mathrm{H}\right]-$ Man6P to Fru6P (4). This indicates an exchange with the solvent rather than exchange between the $\mathrm{C} 1$ and $\mathrm{C} 2$ positions. Both types of exchange have been found with phosphoglucose isomerases (5). Enzymatic assays for PMI revealed a significant specific activity of this enzyme relative to the first enzyme of the PPP, G6PDH, both in rat cortex and in cultured 9L glioma cells (Table 1). Our determination of PMI activity was similar to that reported previously for brain (23) and hypothalamus (24) (Table 1). These results indicate a significant presence of PMI in both normal and tumor tissue. PMI should be considered as a strong candidate for catalyzing the metabolic loss of ${ }^{2} \mathrm{H}$ atoms from glucose molecules labeled in the $\mathrm{C} 1$ position.

${ }^{2} \mathrm{H}$ atoms can also be lost from the C1 or C6 position of glucose, as it is metabolized through glycolysis, via the catalytic action of pyruvate kinase $(\mathrm{PK})$. This reaction consists of a transfer of the phosphoryl group of phosphoenolpyruvate (PEP) to ADP and a transfer of a solvent proton to the C3 position of enolpyruvate to form pyruvate (Fig. $3 \mathrm{~b}$ ). This reaction can also proceed in the reverse direction, causing a selective loss of hydrogen between the keto and enol forms of pyruvate. Evidence for this phenomenon was provided by showing PK-catalyzed enolization of $\left[3-{ }^{3} \mathrm{H}\right]$ pyruvate with subsequent loss of ${ }^{3} \mathrm{H}$, whereas nonenzymatic keto-enol tautomerization of pyruvate was slow (6). Furthermore, detritiation of

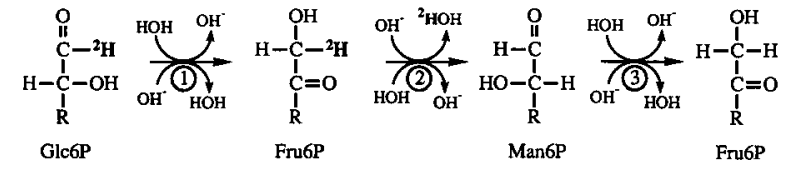

a

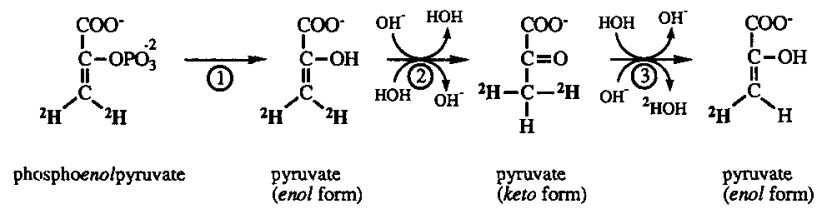

b

FIG. 3. Mechanisms for ${ }^{2} \mathrm{H}$ loss catalyzed by (a) phosphomannose isomerase (PMI) and (b) pyruvate kinase (PK). (a) In step 1, catalyzed by phosphoglucose isomerase (PGI), the ${ }^{1} \mathrm{H}$ atom on $\mathrm{C} 2$ of Glc6P is lost and a hydrogen atom from $\mathrm{H}_{2} \mathrm{O}$ appears on $\mathrm{C} 1$ of Fru6P. In step 2, catalyzed by $\mathrm{PMl}$, the ${ }^{2} \mathrm{H}$ atom on $\mathrm{C} 1$ of Fru6 $\mathrm{P}$ is lost, and an $\mathrm{H}$ atom from $\mathrm{H}_{2} \mathrm{O}$ appears on $\mathrm{C} 2$ of Man6P. In step 3, PMI catalyses the reconversion of Man6P to Fru6P. (b) When pyruvate is produced by the action of $\mathrm{PK}$ (step 1), both ${ }^{2} \mathrm{H}$ atoms on the $\mathrm{C} 3$ position of phosphoenolpyruvate are initially retained and a hydrogen atom from water is added to $\mathrm{C} 3$ (step 2). After rotation of the methyl group around the $\mathrm{C} 2-\mathrm{C} 3$ bond, reconversion to the enol form may result in loss of one of the original ${ }^{2} \mathrm{H}$ atoms (step 3).
Table 1

Phosphomannose Isomerase (PMI) and Glucose 6-Phosphate Dehydrogenase (G6PDH) Activities in Extracts of Rat Brain and Cultured 9L Glioma Cells

\begin{tabular}{lrccc}
\hline Source & PMI $^{\mathrm{a}}$ & G6PDH $^{\mathrm{a}}$ & G6PDH/PMI & Reference \\
\hline 9L glioma & 1.0 & 1.5 & 1.5 & This study \\
Rat cortex & 1.3 & 2.3 & 1.8 & This study \\
Whole brain & 1.3 & & & $(23)$ \\
Hypothalamus & 1.6 & & & $(24)$ \\
\hline
\end{tabular}

${ }^{\text {a }}$ All values are expressed as $\mathrm{U} / 100 \mathrm{mg}$ protein.

$\left[3,3,3-{ }^{3} \mathrm{H}_{3}\right]$ pyruvate in the presence of PK (7) has been shown, and loss of tritium from $\left[3-{ }^{3} \mathrm{H}\right] \mathrm{PEP}$ was reported to occur during the course of the net reaction of PK (8). Metabolism of $\left(6-{ }^{13} \mathrm{C}, 1,6,6-{ }^{2} \mathrm{H}_{3}\right)$ glucose through glycolysis will therefore result in a loss of some of the ${ }^{2} \mathrm{H}$ atoms from labeled pyruvate. Proton exchange with $\left(3-{ }^{2} \mathrm{H}\right)$ pyruvate is expected to have a minor effect on ${ }^{2} \mathrm{H}$ NMR measurements of PPP activity, using $\left(6{ }^{13} \mathrm{C}, 1,6,6-{ }^{2} \mathrm{H}_{3}\right)$ glucose, because the two pyruvate species, $\left(3-{ }^{13} \mathrm{C}, 3,3-{ }^{2} \mathrm{H}_{2}\right)$ pyruvate and $\left(3-{ }^{2} \mathrm{H}\right)$ pyruvate, would have small secondary isotope effects for ${ }^{2} \mathrm{H}$ loss (9).

The extent of ${ }^{2} \mathrm{H}$ loss was estimated by GC/MS analysis after incubation of $9 \mathrm{~L}$ glioma cells with $\left(6-{ }^{13} \mathrm{C}, 6,6-{ }^{2} \mathrm{H}_{2}\right)-$ glucose or $\left(1-{ }^{13} \mathrm{C}, 1-{ }^{2} \mathrm{H}\right)$ glucose. The use of $\left(6-{ }^{13} \mathrm{C}, 6,6-{ }^{2} \mathrm{H}_{2}\right)-$ glucose is expected to result in ${ }^{2} \mathrm{H}$ loss by $\mathrm{PK}$ activity, whereas $\left(1-{ }^{13} \mathrm{C}, 1-{ }^{2} \mathrm{H}\right)$ glucose may lose ${ }^{2} \mathrm{H}$ by both PK and PMI activities. GC/MS analysis of media from 9L cells incubated with these precursors have indicated 6-14\% ${ }^{2} \mathrm{H}$ loss from the $\mathrm{C} 6$ position of glucose and an additional 14-38\% ${ }^{2} \mathrm{H}$ loss from the C1 position, presumably by PMI (15).

Numerous studies have used ${ }^{2} \mathrm{H}$ NMR and ${ }^{3} \mathrm{H}$ NMR spectroscopy to assess various aspects of intermediary metabolism (1, 2, 10). For example, it has been shown that when $\left[1-{ }^{3} \mathrm{H}\right]$ glucose was used as precursor in packed erythrocytes, $15 \%$ of the final tritium signal appeared as ${ }^{3} \mathrm{HOH}$ in the ${ }^{3} \mathrm{H}$ NMR spectrum (10). Because the PPP, coupled to the glutathione pathway, provides a metabolic sequence to incorporate tritium into water, it was suggested that the intensity of the ${ }^{3} \mathrm{HOH}$ resonance "must reflect" PPP activity (10). However, the ${ }^{3} \mathrm{HOH}$ intensity also reflects other enzyme activities, including PMI and $\mathrm{PK}$, and the PPP is probably a minor contributor to ${ }^{3} \mathrm{HOH}$ production under basal conditions. It is therefore misleading to suggest that ${ }^{3} \mathrm{HOH}$ production "reflects" PPP activity any more than it reflects the other enzyme activities.

In summary, the use of $\left(6-{ }^{13} \mathrm{C}, 1,6,6{ }^{2} \mathrm{H}_{3}\right)$ glucose resulted in an overestimation of the activity of the PPP, presumably as a result of PMI-catalyzed ${ }^{2} \mathrm{H}$ loss from the $\mathrm{C} 1$ position of this molecule. However, the use of ${ }^{2} \mathrm{H}$ NMR with ${ }^{2} \mathrm{H}$-enriched precursors such as $\left(6-{ }^{13} \mathrm{C}, 1,6,6-{ }^{2} \mathrm{H}_{3}\right)$ glucose may prove beneficial in the study of proton exchange reactions in vitro or in vivo, because the extent of selective ${ }^{2} \mathrm{H}$ loss from the $\mathrm{C} 1$ position may be correlated with specific metabolic or pathological conditions.

\section{ACKNOWLEDGMENT}

The authors wish to thank Chris Antczak for technical assistance. 


\section{REFERENCES}

1. K. D. Barrow, P. L. Rogers, G. M. Smith, NMR studies of [1${ }^{2} \mathrm{H}$ ]glucose metabolism in Zymomonas mobilis. Eur. J. Biochem. 157, 195-202 (1986).

2. J. B. Aguayo, M. P. Gamcsik, J. D. Dick, High resolution deuterium NMR studies of bacterial metabolism. J. Biol. Chem. 263, 19552-19557 (1988).

3. Y. J. Topper, On the mechanism of action of phosphoglucose isomerase and phosphomannose isomerase. J. Biol. Chem. 225, 419-425 (1957).

4. I. A. Rose, Z. B. Rose, Glycolysis: regulation and mechanisms of enzymes. Compr. Biochem. 17, 93-161 (1969).

5. I. A. Rose, E. L. O'Connell, Intramolecular hydrogen transfer in the phosphoglucose isomerase reaction. J. Biol. Chem. 236, 3086-3092 (1961).

6. I. A. Rose, Studies on the enolization of pyruvate by pyruvate kinase. J. Biol. Chem. 235, 1170-1177 (1960).

7. H. Simon, R. Medina, G. Mullhofer, Studies on carbohydrate metabolism by means of hydrogen labeling. 3. Measurement of T-fixation during some sequences of glycolysis. $Z$. Naturforch. 23b, 59-64 (1968).

8. J. L. Robinson, I. A. Rose, The proton transfer reactions of muscle pyruvate kinase. J. Biol. Chem. 247, 1096-1105 (1972).

9. W. K. Saur, D. T. Peterson, E. A. Halevi, H. L. Crespi, J. J. Katz, Deuterium isotope effects in the fermentation of hexoses to ethanol by Saccharomyces cerevisiae. II. A steadystate kinetic analysis of the isotopic composition of the methyl group of ethanol in an isotopic mirror fermentation experiment. Biochemistry 7, 3537-3546 (1968).

10. R. D. Newmark, S. Un, P. G. Williams, P. J. Carson, H. Morimoto, M. P. Klein ${ }^{3} \mathrm{H}$ nuclear magnetic resonance studies of anaerobic glycolysis in packed erythrocytes. Proc. Natl. Acad. Sci. (USA) 87, 583-587 (1990).

11. H. G. Wood, J. Katz, B. R. Landau, Estimation of pathways of carbohydrate metabolism. Biochem. Z. 338, 809-817 (1963).

12. J. A. Willis, W. F. Williams, T. Schleich, Dynamic assessment of hexose monophosphate shunt activity in intact rabbit lens by proton NMR spectroscopy. Biochem. Biophys. Res. Commun. 138, 1068-1073 (1986).

13. S. L. Mitchell, B. D. Ross, T. Krick, M. Garwood, Gas chromatographic-mass spectrometric analysis of hexose mono- phosphate shunt activity in cultured cells. Biochem. Biophys. Res. Commun. 158, 474-479 (1989).

14. P. B. Kingsley-Hickman, B. D. Ross, T. Krick, Hexose monophosphate shunt measurement in cultured cells with [1$\left.{ }^{13} \mathrm{C}\right]$ glucose: Correction for endogenous carbon sources using $\left[6-{ }^{13} \mathrm{C}\right]$ glucose. Anal. Biochem. 185, 235-237 (1990).

15. B. D. Ross, P. B. Kingsley, O. Ben-Yoseph, Measurement of the pentose phosphate pathway in a single incubation with $\left(1,6-{ }^{13} \mathrm{C}_{2}, 6,6-{ }^{2} \mathrm{H}_{2}\right)$ glucose. Biochem J. 302, 31-38 (1994).

16. S. Kang, A. Markovitz, Induction of capsular polysaccharide synthesis by p-fluorophenylalanine in Escherichia coli wild type and strains with altered phenylalanyl soluble ribonucleic acid synthetase. J. Bacteriol. 93, 584-591 (1967).

17. G. W. Lohr, H. D. Waller, "Methods of Enzymic Analysis" (H. U. Bergmeyer, Ed.), Vol. 2, p. 636, Academic Press, New York, 1974.

18. S. T. Ohnishi, J. K. Barr, A simplified method of quantitating protein using the biuret and phenol reagents. Anal. Biochem. 86, 193-200 (1978).

19. S. C. Hubbard, R. J. Ivatt, Synthesis and processing of asparagine-linked oligosaccharides. Annu. Rev. Biochem. 50, 555-583 (1981).

20. S. K. Guha, Z. B. Rose, The synthesis of mannose 1-phosphate in the brain. Arch. Biochem. Biophys. 243, 168-173 (1985).

21. N. R. Bhat, C. J. Waechter, Induction of N-glycosylation activity in cultured embryonic rat brain cells. J. Neurochem. 50, 375-381 (1988).

22. B. Lossner, R. Jork, M. Linder, B. Lucke, H. Matthies, Dopamine stimulated glycosylation of brain proteins in vitro is inhibited only partially by dopamine receptor antagonists. Biomed. Biochim. Acta 43, 775-787 (1984).

23. N. Z. Baquer, P. McLean, Evidence for the existence and functional activity of the pentose phosphate pathway in the large particle fraction isolated from rat tissues. Biochem. Biophys. Res. Commun. 46, 167-174 (1972).

24. J. C. Lai, T. K. Leung, W. Marr, L. Lim, The activity of glucose 6-phosphate dehydrogenase in liver and hypothalamus of the female rat: effects of administration of ethinyloestradiol and the progestogens norethisterone acetate and d-norgestrel. Biochem. Soc. Trans. 8, 606 (1980). 